\title{
Pertumbuhan Batang Bawah Karet pada Beberapa Komposisi Media Tanam dalam Root Trainer
}

\section{(Hevea Rubber Rootstock Growth with Several Planting Media Compositions in Root Trainer)}

\author{
Junaidi $^{1^{*}}$, Atminingsih ${ }^{1}$, Eka Boby Febrianto ${ }^{2}$, Rina Maharany ${ }^{2}$
}

(Diterima Mei 2020/Disetujui Juli 2020)

\begin{abstract}
ABSTRAK
Pembibitan batang bawah karet dengan metode root trainer bertujuan mendorong pertumbuhan akar melalui penggunaan media tanam non-tanah dalam wadah kontainer khusus. Teknologi ini menawarkan kelebihan proses pembibitan yang singkat, perakaran yang baik, dan kemudahan pengiriman. Penelitian ini bertujuan mengetahui pengaruh komposisi media tanam tandan kosong kelapa sawit, pupuk kandang, sekam padi, decanter solid, dan Trichoderma viride pada pertumbuhan batang bawah tanaman karet dengan metode root trainer. Penelitian ini dilaksanakan di rumah kaca Balai Penelitian Sungei Putih, Pusat Penelitian Karet, Deli Serdang, Sumatera Utara pada Januari-Mei 2019. Pengamatan dilakukan pada parameter tinggi tanaman, jumlah daun, diameter batang, panjang dan bobot kering akar, dan persentase keberhasilan okulasi. Hasil penelitian menunjukkan bahwa campuran tandan kosong, decanter solid, dan Trichoderma viride (perlakuan $\mathrm{T}_{\mathrm{e}}$ ) paling potensial dikembangkan sebagai media tanam untuk pembibitan batang bawah karet dengan sistem root trainer. Pada 18 minggu setelah tanam, perlakuan $T_{e}$ memiliki rata-rata tinggi tanaman $82,66 \pm 14,27 \mathrm{~cm}$ dengan pertambahan tinggi $3,25 \pm 0,81 \mathrm{~cm} / \mathrm{minggu}$, jumlah daun $11,33 \pm 3,21$ helai dengan rata-rata pertambahan $0,52 \pm 0,20$ helai/minggu, diameter batang $5,29 \pm 0,73 \mathrm{~mm}$ dengan pertambahan $0,33 \pm 0,05 \mathrm{~mm} / \mathrm{minggu}$. Perlakuan $\mathrm{T}_{\mathrm{e}}$ memiliki panjang akar dan bobot akar $41,97 \pm 2,40 \mathrm{~cm}$ dan 1,68 \pm $0,77 \mathrm{~g}$ dengan persentase keberhasilan okulasi sebesar $47,37 \%$. Selain menunjukkan pertumbuhan yang baik, bahanbahan tersebut juga tersedia dalam jumlah besar dan kontinyu. Penggunaan Trichoderma viride selain dapat meningkatkan pertumbuhan tanaman juga sebagai antisipasi terhadap penyakit jamur akar putih.
\end{abstract}

Kata kunci: batang bawah, Hevea brasiliensis, media tanam, pertumbuhan, root trainer

\section{ABSTRACT}

The rubber tree rootstock nursery using the root trainer method is aimed to promote root growth through the use of non-soil growing media in a special container. This technology offers the advantages of a shortened breeding process, good rooting, and ease of delivery. The objective of this study is to investigate the effect of the planting media composition of oil palm bunches compost, manure, rice husk, solid decanter, and Trichoderma viride on the growth of rubber rootstock under the root trainer method. The research was carried out in the greenhouse of the Sungei Putih Research Center, Indonesian Rubber Research Institute, Deli Serdang, North Sumatra in January-May 2019. The observation included plant height, number of leaves, stem diameter, dry weight, and root length, and successful grafting percentage. The results indicated that the mixture of oil palm bunches compost, solid decanter, and Trichoderma viride ( $T_{e}$ treatment) was the most potential to be developed as a planting media for rubber rootstock nursery under root trainer system. At 18 weeks after planting, the $T_{e}$ treatment had an average height of $82.66 \pm 14.27$ $\mathrm{cm}$ with an increment rate of $3.25 \pm 0.81 \mathrm{~cm} /$ week, number of leaves $11.33 \pm 3.21$ leaves with the increment of $0.52 \pm$ 0.20 leaves/week, stem diameter $5.29 \pm 0.73 \mathrm{~mm}$ with an increase of $0.33 \pm 0.05 \mathrm{~mm} /$ week. The Te treatment had $\bar{a}$ length and root weight of $41.97 \pm 2.40 \mathrm{~cm}$ and $1.68 \pm 0.77 \mathrm{~g}$, respectively, with the grafting successfulness percentage of $47.37 \%$. Besides showing good growth, these materials are also available in large and continuous quantities. The use of Trichoderma viride not only for increasing plant growth but also as a biocontrol of white root disease.

Keywords: growth, growing media, Hevea brasiliensis, rootstock, root trainer

\section{PENDAHULUAN}

Tanaman karet umumnya diperbanyak dengan cara okulasi, yaitu penempelan mata tunas (scion) pada

${ }^{1}$ Balai Penelitian Sungei Putih, Pusat Penelitian Karet, Galang, Deli Serdang, Po. Box 1415 Medan 20001

2 Sekolah Tinggi IImu Pertanian Agrobisnis Perkebunan (STIPAP) Medan, Jl. Williem Iskandar, Medan Estate, Deli Serdang, Sumatera Utara 20226

*Penulis Korespondensi: Email: junaidi.sp5@gmail.com batang bawah (rootstock). Pembibitan batang bawah biasanya dilakukan di lapangan sampai dihasilkan stum okulasi mata tidur (SOMT), selanjutnya dipelihara di pembibitan polibeg sampai siap tanam. Metode lainnya adalah pembibitan langsung di polibeg dengan media top soil (Siagian \& Bukit, 2015). Kelemahan sistem pembibitan ini adalah penyiraman secara terus menerus yang dapat menyebabkan media tanah menjadi padat sehingga menghambat pembentukan sistem perakaran. Selain itu, bibit polibeg berukuran 
besar dan berat sehingga menyulitkan pengiriman dan penanaman di lapangan. Pada saat ini berkembang metode pembibitan dengan metode root trainer. Teknik ini menawarkan kelebihan proses pembibitan yang singkat, perakaran yang baik, dan kemudahan pengiriman (George et al., 2013; Salisu et al., 2016).

Root trainer mendorong pertumbuhan akar melaui penggunaan media tanam non-tanah dalam wadah kontainer khusus. Teknologi ini sudah umum digunakan untuk pembibitan tanaman (Bashir et al. 2009; Rashid et al. 2018), namun untuk tanaman karet masih tergolong baru. Pada awalnya teknologi ini diperkenalkan di India untuk memudahkan pengangkutan di daerah berbukit, dan pada saat ini mulai diadopsi di negera-negara penghasil karet alam lainnya, termasuk Indonesia (Ardika dan Herlinawati, 2014; Ardika et al. 2017). Penelitian Putra et al. (2018) menunjukkan bahwa penggunaan pupuk organik briket rawa pening dapat meningkatkan biomass bibit karet. Akan tetapi, media ini hanya tersedia terbatas di daerah Ambarawa, Jawa Tengah. Junaidi (2018) menyatakan bahwa salah satu tantangan penerapan teknologi root trainer adalah ketersediaan media dalam jumlah besar dan kontinu.

Untuk mendorong pertumbuhan akar yang optimal diperlukan media yang memiliki porositas dan kandungan hara yang baik. Tandan kosong dan decanter solid merupakan limbah pengolahan kelapa sawit yang selalu tersedia melimpah di pabrik-pabrik pengolahan kelapa sawit dan berpotensi digunakan sebagai media pembibitan karet. Bahan-bahan tersebut sudah banyak digunakan untuk kegiatan budi daya tanaman (Budiyanto 2018; Maryani 2018). Penelitian Saputra \& Stevanus (2019) menunjukkan aplikasi tandan kosong kelapa sawit dapat meningkatkan pertumbuhan tanaman karet. Bibit karet hasil pembibitan di lapangan sangat rentan terserang penyakit jamur akar putih yang ditularkan lewat tanah. Trichoderma adalah agensia hayati yang efektif untuk mengendalikan patogen penyebab jamur akar putih (Rigidoporus microphorus) (Fairuzah et al. 2014; Yulia et al. 2017). Bahan lain, seperti pupuk kandang dan sekam padi, sering digunakan untuk budi daya tanaman hias dan hortikultura. Akan tetapi, penelitian penggunaan bahan-bahan tersebut untuk pembibitan karet, khususnya dengan metode root trainer, belum pernah dilakukan.

Bahan tanam yang berkualitas merupakan salah satu syarat untuk mempersingkat masa tanaman belum menghasilkan (TBM) (Boerhendy et al. 2012). Penelitian ini bertujuan mengetahui pengaruh komposisi media tanam tandan kosong kelapa sawit, pupuk kandang, sekam padi, decanter solid, dan Trichoderma viride pada pertumbuhan batang bawah tanaman karet dengan metode root trainer. Hipotesis yang diajukan pada penelitian ini adalah terdapat pengaruh yang signifikan komposisi media tanam pada pertumbuhan dan keberhasilan okulasi batang bawah karet dengan metode root trainer. Hasil penelitian ini berguna bagi perusahaan perkebunan dan penangkar bibit karet dalam perbanyakan bahan tanam karet berkualitas.

\section{METODE PENELITIAN}

\section{Lokasi Penelitian dan Persiapan Media}

Penelitian ini dilaksanakan di rumah kaca Balai Penelitian Sungei Putih, Pusat Penelitian Karet, Deli Serdang, Sumatera Utara pada Januari-Mei 2019. Media tanam yang digunakan dalam penelitian ini meliputi tandan kosong kelapa sawit, pupuk kandang sapi, decanter solid, sekam padi, dan Trichoderma viride. Tandan kosong dan decanter solid merupakan limbah padat pabrik pengolahan kelapa sawit Kebun Sei Daun, PT. Perkebunan Nusantara III, Sumatera Utara, sedangkan pupuk kandang dan sekam padi diperoleh dari peternak sapi dan penggilingan padi di sekitar lokasi penelitian. Trichoderma viride diperoleh dari Laboratorium Proteksi Tanaman, Balai Penelitian Sungei Putih.

Pupuk kandang dan decanter solid yang digunakan telah matang. Semua bahan, kecuali Trichoderma viride, diayak dengan ukuran 18 mesh. Campuran media tanam menggunakan perbandingan volume (1: $1: 1)$ sebagaimana disajikan pada Tabel 1 . Root trainer yang digunakan berupa kontainer polipropilen berbentuk silindris, diameter atas $6,0-7,5 \mathrm{~cm}$, diameter bawah 1,5-2,0 cm, dan tinggi $30,0 \mathrm{~cm}$. Rata-rata daya tampung root trainer adalah $800 \mathrm{~mL}$. Pada bagian dalam terdapat alur vertikal, sedangkan pada bagian bawah dilengkapi lubang drainase (Gambar 1a). Selama penelitian, root trainer disusun dalam rak kayu dengan ketinggian $45,0 \mathrm{~cm}$ dari permukaan lantai rumah kaca (Gambar $1 b)$.

\section{Persemaian Biji dan Pemeliharaan}

Biji karet yang digunakan berasal dari klon PB 260 yang merupakan salah satu klon anjuran batang bawah (Boerhendhy 2009) dari tanaman berumur 15 tahun di Kebun Percobaan Balai Penelitian Sungei Putih. Persemaian biji dilakukan dalam rumah kaca dengan

Tabel 1 Komposisi media tanam yang diuji coba pada pembibitan batang bawah tanaman karet dengan metode root trainer

\begin{tabular}{cl}
\hline Perlakuan & \multicolumn{1}{c}{$\begin{array}{c}\text { Komposisi media } \\
(\mathrm{v}: \mathrm{v}: \mathrm{v})\end{array}$} \\
\hline $\mathrm{T}_{\mathrm{a}}$ & Tandan kosong : pupuk kandang : decanter solid \\
$\mathrm{T}_{\mathrm{b}}$ & Tandan kosong : pupuk kandang : sekam padi \\
$\mathrm{T}_{\mathrm{c}}$ & Tandan kosong : pupuk kandang : Trichoderma viride \\
$\mathrm{T}_{\mathrm{d}}$ & Tandan kosong : sekam padi : Trichoderma viride \\
$\mathrm{T}_{\mathrm{e}}$ & Tandan kosong : decanter solid : Trichoderma viride \\
\hline
\end{tabular}




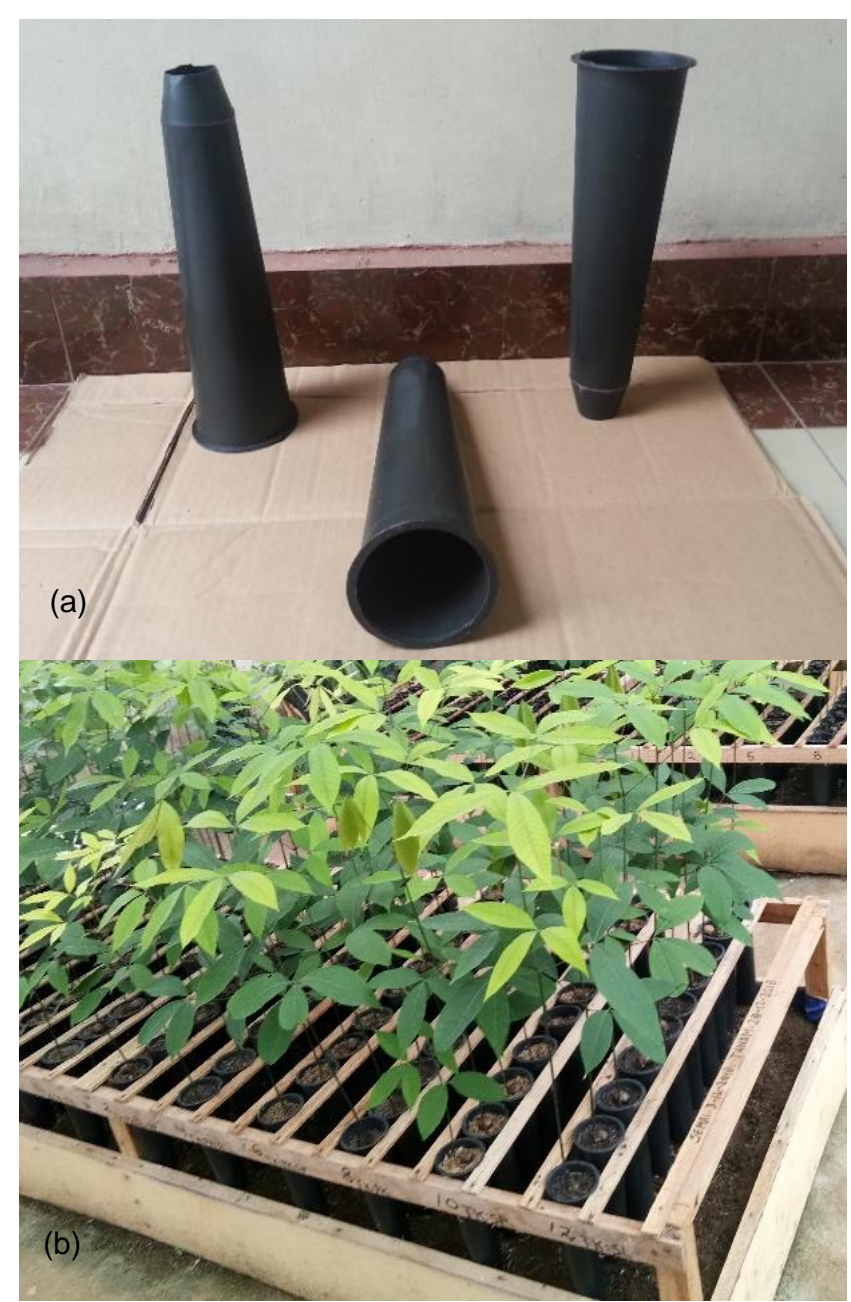

Gambar 1 a) Root trainer untuk pembibitan batang bawah karet dan b) Pertumbuhan tanaman dengan metode pembibtian root trainer.

media pasir sungai. Selama persemaian, penyiraman dilakukan setiap hari. Kecambah karet diseleksi pada 15 hari setelah semai, kecambah yang ditanam pada masing-masing root trainer adalah stadia jarum yang ditandai dengan tunas yang lancip menyerupai jarum. Pengacakan dilakukan menurut Rancangan Acak Kelompok (RAK) dengan tiga ulangan, setiap satuan percobaan terdiri atas 10 root trainer. Selama pembibitan, kegiatan pemeliharaan dilakukan sesuai standar yang meliputi penyiraman setiap hari dan pengendalian gulma manual seminggu sekali.

\section{Pengamatan dan Analisis Statistik}

Pengamatan dilakukan pada parameter tinggi tanaman, jumlah daun, diameter batang, panjang dan bobot kering akar, dan persentase keberhasilan okulasi. Tinggi tanaman, jumlah daun, dan diameter batang diamati setiap dua minggu sekali. Setelah tanaman berumur 18 minggu, tiga tanaman pada masing-masing perlakuan, yang dipilih secara acak, dicabut dan dibersihkan untuk diukur panjang akarnya. Bobot kering akar diperoleh melalui pengeringan dalam oven pada suhu $60^{\circ} \mathrm{C}$ selama 24 jam (Nayanakantha et al. 2015).
Okulasi dilakukan serentak pada saat batang bawah berumur 18 mst dengan teknik okulasi hijau (green budding) menggunakan mata sisik klon PB 260 yang diperoleh dari Kebun Percobaan Balai Penelitian Sungei Putih. Keberhasilan okulasi diperiksa tiga minggu setelah okulasi. Persentase keberhasilan okulasi adalah perbandingan jumlah okulasi berhasil dengan jumlah total tanaman yang diokulasi.

Analisis statistik dilakukan menggunakan $R$ Statistic Software version 3.6.3 (R Development Core Team) dengan interface $R$ Studio version 1.2.5033 (R Studio Inc.). Analysis of Variance (ANOVA) dilakukan untuk semua parameter pengamatan.

\section{HASIL DAN PEMBAHASAN}

\section{Tinggi Tanaman dan Jumlah Daun}

Hasil pengamatan menunjukkan bahwa tinggi tanaman pada semua perlakuan yang diujicobakan relatif sama sampai $6 \mathrm{mst}$. Setelah enam minggu, tinggi tanaman pada perlakuan $T_{e}$ lebih tinggi dibanding perlakuan lainnya, dan perlakuan $T_{b}, T_{c}$, dan $T_{d}$ cenderung sama, sedangkan $\mathrm{T}_{\mathrm{a}}$ paling rendah. Pada umur $18 \mathrm{mst}$, rata-rata tanaman yang paling tinggi adalah pada perlakuan $\mathrm{T}_{\mathrm{e}}(82,66 \pm 14,27 \mathrm{~cm})$, sedangkan terendah pada perlakuan $\mathrm{T}_{\mathrm{a}}$ dengan tinggi rata-rata $60,95 \pm 8,12 \mathrm{~cm}$. Tinggi tanaman pada perlakuan $T_{b}, T_{c}$, dan $T_{d}$ masing-masing adalah 73,60 $\pm 8,27 \mathrm{~cm}, 74,57 \pm 10,87 \mathrm{~cm}$, dan 70,14 $\pm 12,96 \mathrm{~cm}$ (Gambar 2a). Gambar 2b menunjukkan rata-rata laju pertambahan tinggi tanaman selama 18 minggu pengamatan. Laju pertambahan yang tertinggi sebesar $3,25 \pm 0,81 \mathrm{~cm} /$ minggu ditemukan pada perlakuan $T_{e}$, sedangkan yang terendah sebesar 2,01 \pm 0,27 $\mathrm{cm} /$ minggu ditemukan pada perlakuan $\mathrm{T}_{\mathrm{a}}$.

Rata-rata jumlah daun yang paling banyak diperoleh pada perlakuan $T_{e}$, yaitu 11,33 $\pm 3,21$ dan $T_{c}$ sebanyak 11,00 $\pm 3,61$ helai per tanaman. Jumlah daun yang paling sedikit adalah pada perlakuan $T_{a}$, dengan rata-rata hanya 6,67 $\pm 1,53$ helai per tanaman. Jumlah daun yang rendah pada perlakuan $T_{a}$ disebabkan oleh kerontokan daun tua pada $14 \mathrm{mst}$ (Gambar 2c). Adapun perlakuan $\mathrm{T}_{\mathrm{b}}$ dan $\mathrm{T}_{\mathrm{d}}$ masingmasing memiliki rata-rata jumlah daun $9,67 \pm 2,52$ helai dan 9,33 $\pm 3,79$ helai per tanaman. Perlakuan $T_{e}$ dan $T_{c}$ memiliki laju pertambahan jumlah daun yang sama, yaitu masing-masing $0,52+0,20$ dan $0,52+0,19$ helai per minggu (Gambar 2d). Laju pertambahan jumlah daun terendah ditemukan pada perlakuan $\mathrm{T}_{\mathrm{a}}$, yaitu $0,23 \pm 0,10$ helai per minggu.

Pengamatan pertumbuhan tajuk (tinggi tanaman dan jumlah daun) sampai dengan 18 mst menunjukkan bahwa komposisi perlakuan $\mathrm{T}_{\mathrm{e}}$ dengan komposisi tandan kosong, decanter solid, dan Trichoderma viride (perbandingan volume 1:1:1) memiliki pertumbuhan paling baik dibanding perlakuan lainya, meskipun secara satistik tidak berbeda nyata. Alternatif perlakuan yang menunjukkan pertumbuhan tajuk yang cukup baik selain $T_{e}$ adalah perlakuan $T_{c}$ (tandan 
kosong : pupuk kandang : Trichoderma viride). Kedua perlakuan tersebut sama-sama menggunakan tandan kosong dan Trichoderma viride, yang membedakan adalah perlakuan $T_{e}$ menggunakan decanter solid, sedangkan $T_{c}$ menggunakan pupuk kandang. Hal ini menunjukkan bahwa kedua bahan tersebut kemungkinan dapat saling menggantikan. Pada penelitian ini tidak dilakukan analisis hara yang terkandung dalam media tanam, namun berdasarkan literatur kandungan hara, terutama nitrogen, pada pupuk kandang relatif sama dengan pada decanter solid (Tabel 2).

Ketersediaan tandan kosong kelapa sawit dan decanter solid cukup melimpah karena Indonesia memiliki 14,67 juta ha perkebunan kelapa sawit dengan ribuan pabrik pengolahan yang tersebar di seluruh Indonesia (Direktorat Jenderal Perkebunan,
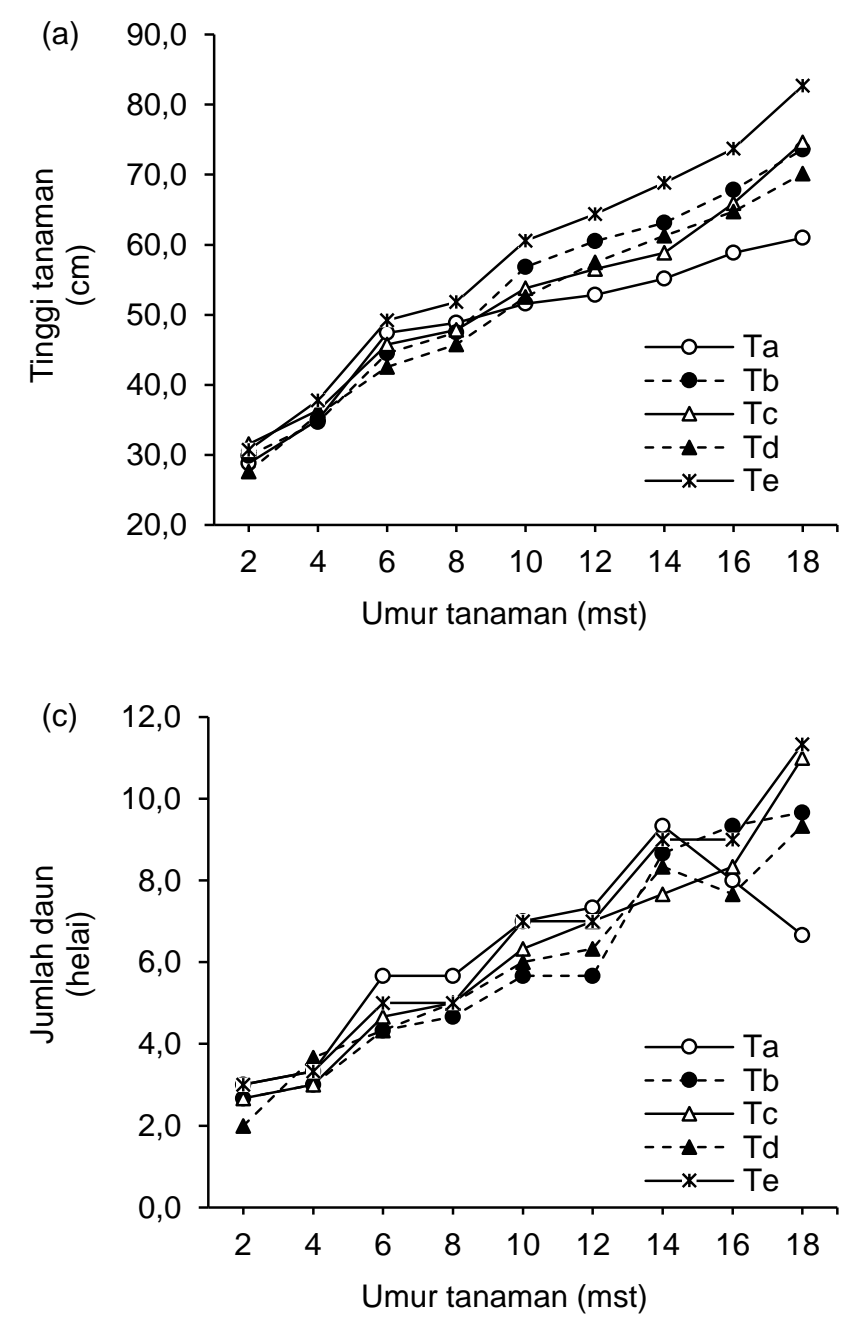

2018). Decanter solid telah banyak diteliti di antaranya untuk pembibitan kelapa sawit (Maryani 2018), karet (Harahap et al. 2018), dan budi daya sayuran (Rohaeni 2017). Dalam kondisi decanter solid sulit diperoleh, berdasarkan hasil penelitian ini, decanter solid dapat diganti dengan pupuk kandang. Pupuk kandang telah dikenal secara luas sebagai pupuk organik dan banyak digunakan untuk budi daya sayuran dan tanaman hias (Maryam et al. 2015; Lestari 2016; Putra et al. 2017; Setiadi et al. 2018).

Trichoderma viride adalah spesies jamur yang umumnya digunakan untuk pengendalian hayati penyakit akar (Zegeye et al. 2011; Purwantisari et al. 2018). Pada tanaman karet, T. viride terutama ditujukan untuk mengatasi penyakit jamur akar putih (Rigidoporus microphorus) (Setyawan et al. 2013). Aplikasi $T$. viride pada perlakuan $\mathrm{T}_{\mathrm{e}}$ dan $\mathrm{T}_{\mathrm{c}}$
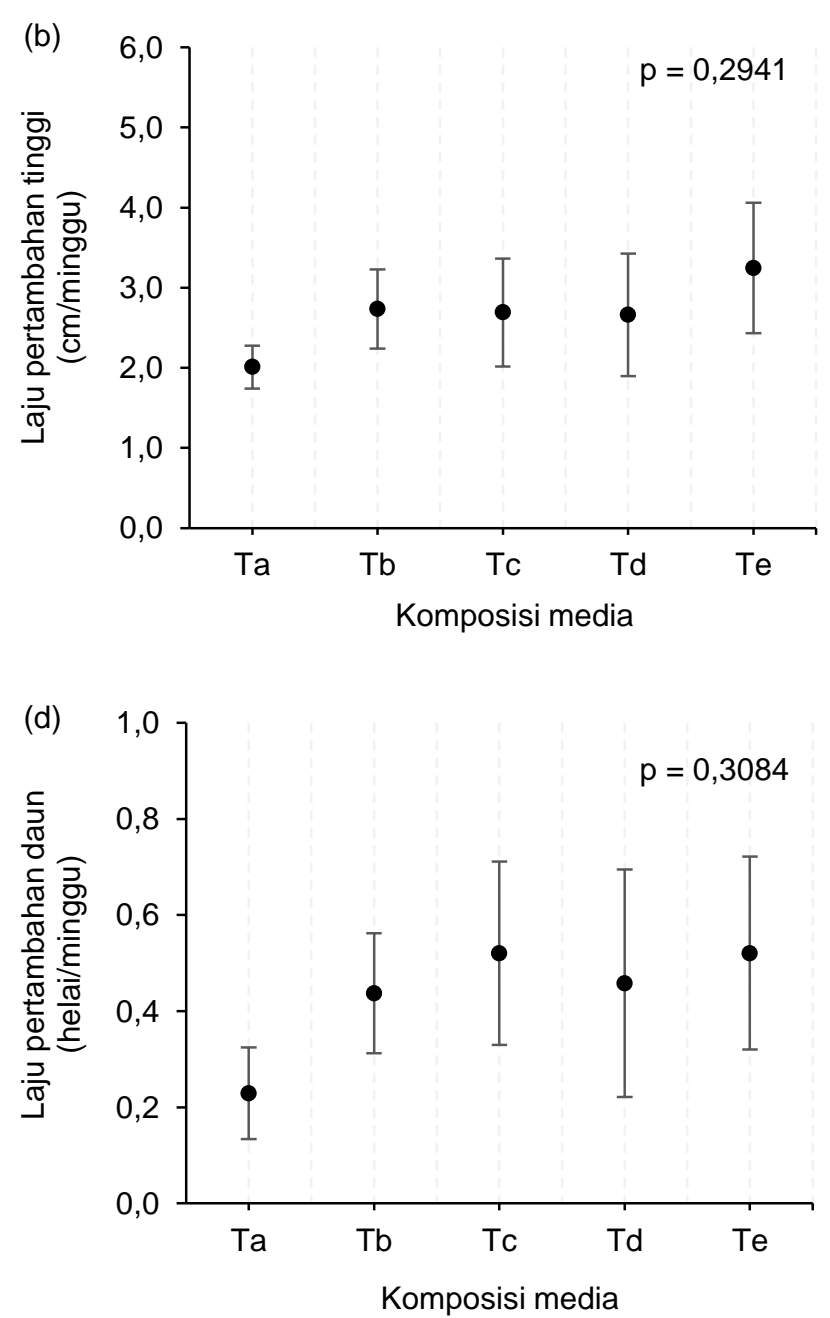

Gambar 2 Tinggi tanaman (a), laju pertambahan tinggi tanaman (b), jumlah daun (c), dan laju pertambahan jumlah dauh (d) masing-masing perlakuan sampai dengan 18 minggu pengamatan.

Tabel 2 Kandungan hara utama yang terkandung dalam pupuk kandang, tandan kosong, dan decanter solid

\begin{tabular}{lccccl}
\hline \multirow{2}{*}{ Bahan tanam } & \multicolumn{4}{c}{ Kandungan hara (\%) } & \multirow{2}{*}{ Referensi } \\
\cline { 2 - 5 } & $\mathrm{C}$ & $\mathrm{N}$ & $\mathrm{P}$ & $\mathrm{K}$ & \\
\hline Pupuk kandang & 24,57 & 1,63 & 0,26 & 2,80 & Sudarsono et al. (2013) \\
Tandan kosong & $42-54$ & $3-5$ & $0,4-1$ & $2,9-5,2$ & Saputra dan Stevanus (2019) \\
Decanter solid & 14,40 & 1,47 & 0,17 & 0,99 & Yuniza (2015) dalam Maryani (2018 \\
\hline
\end{tabular}


menunjukkan pertumbuhan tanaman cukup baik sejalan dengan penelitian Topolovec-Pintaric et al. (2013) yang menunjukkan bahwa aplikasi $T$. viride dapat meningkatkan pertumbuhan tanaman kubis dan bit. Hasil penelitian ini menunjukkan bahwa aplikasi $T$. viride tidak hanya bermanfaat untuk pencegahan penyakit jamur akar putih, namun juga berguna untuk meningkatkan pertumbuhan tanaman.

\section{Diameter Batang dan Biomassa Akar}

Diameter batang merupakan parameter penting pada pembibitan karet. Semakin tinggi pertambahan diameter batang maka semakin cepat tanaman dapat diokulasi. Pada $18 \mathrm{mst}$, perlakuan dengan diameter paling tinggi adalah $\mathrm{T}_{\mathrm{e}}$, rata-rata diameter $5,29 \pm 0,73$ $\mathrm{mm}$, sedangkan terendah pada $T_{\text {a }}$ sebesar $4,07 \pm 0,33$ $\mathrm{mm}$. Adapun diameter pada perlakuan $\mathrm{T}_{\mathrm{b}}, \mathrm{T}_{\mathrm{c}}$, dan $\mathrm{T}_{\mathrm{d}}$ masing-masing adalah 4,77 $\pm 0,49 \mathrm{~mm}, 4,81 \pm 0,38$ $\mathrm{mm}$, dan 4,44 \pm 0,52 mm (Gāmbar 3a). Berdasarkan data diameter yang diukur setiap dua minggu, laju pertambahan diameter tertinggi sebesar 0,33 $\pm 0,05$ $\mathrm{mm} /$ minggu ditemukan pada perlakuan $\mathrm{T}_{\mathrm{e}}$, sedangkan terendah 0,25 $\pm 0,02 \mathrm{~mm} / \mathrm{ming} g u$ ditemukan pada perlakuan $\mathrm{T}_{\mathrm{a}}$ (Gambar $\left.3 \mathrm{~b}\right)$. Hasil pengamatan
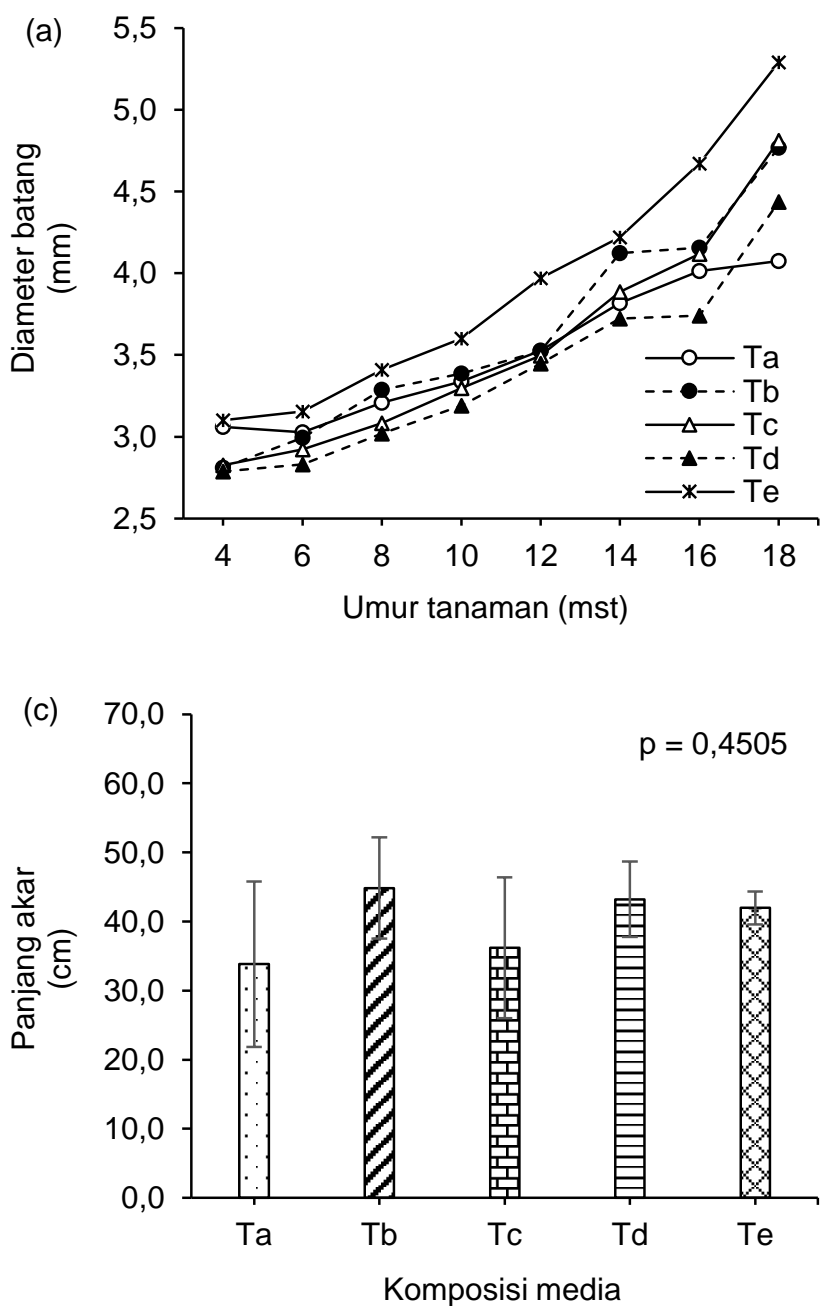

menunjukkan bahwa $T_{e}$, perlakuan yang memiliki pertumbuhan tajuk yang paling baik, juga memiliki pertumbuhan diameter yang paling tinggi. Hal ini diduga terkait dengan jumlah daun sebagai sumber fotosintat yang diperlukan untuk pertumbuhan sekunder. Menurut Deslauriers et al. (2009), laju diferensiasi jaringan meristem batang berkaitan dengan ketersediaan karbon dalam zona kambium. Diferensiasi sel kambium vaskuler merupakan faktor yang menentukan pertambahan diameter batang, proses ini membutuhkan energi yang diperoleh dari fotosintat (Spicer \& Groover 2010; Wang \& Ruan 2016).

Dalam pembibitan tanaman karet, batang bawah (rootstock) diokulasi dengan mata tunas (scion) dari klon unggul. Batang bawah selanjutnya akan menjadi pangkal batang dan sistem perakaran. Oleh sebab itu, kemampuan pembentukan perakaran merupakan parameter penting. Rata-rata panjang akar masingmasing perlakuan disajikan pada Gambar 3c, sedangkan bobot kering akar pada umur $18 \mathrm{mst}$ disajikan pada Gambar 3d. Panjang akar tidak berbeda nyata antarperlakuan, perlakuan $\mathrm{T}_{\mathrm{b}}$ memiliki rata-rata panjang akar tertinggi $(44,83 \pm 7,33 \mathrm{~cm})$, sedangkan
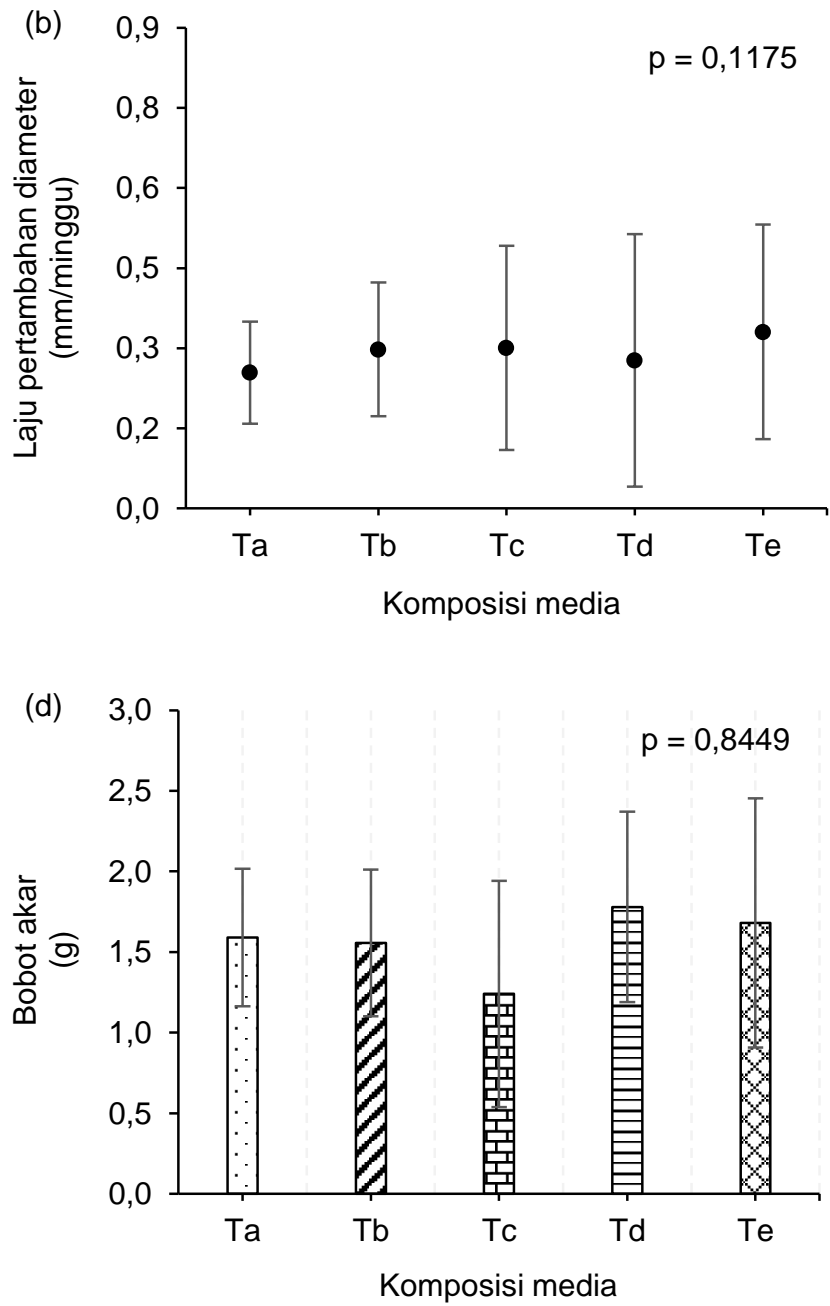

Gambar 3 Diameter batang (a), laju pertambahan diameter batang (b), panjang akar (c), dan bobot akar (d) masing-masing perlakuan sampai dengan 18 minggu pengamatan. 
terendah pada perlakuan $\mathrm{T}_{\mathrm{a}}(33,83 \pm 11,98 \mathrm{~cm})$. Perlakuan $T_{b}$ juga memiliki bobot akar paling tinggi $(1,78 \pm 0,59 \mathrm{~g})$, sedangkan bobot akar terendah diperoleh pada perlakuan $T_{c}(1,24 \pm 0,70 \mathrm{~g})$. Perlakuan $\mathrm{T}_{e}$ yang memiliki pertumbuhan tajuk paling baik, juga menunjukkan panjang akar dan bobot akar yang cukup tinggi, yaitu $41,97 \pm 2,40 \mathrm{~cm}$ dan $1,68 \pm 0,77 \mathrm{~g}$.

Sistem perakaran sangat penting untuk menopang tajuk, menyerap unsur hara, dan adaptasi terhadap lingkungan (Feng et al. 2011; Wattanasilakorn et al. 2012; Wattanasilakorn et al. 2017). Pada penelitian ini, perlakuan $T_{b}$ memiliki panjang akar yang paling tinggi, namun dengan bobot akar yang lebih rendah dibanding perlakuan $T_{d}$ dan $T_{e}$. Perlakuan $T_{d}$ menunjukkan pertumbuhan akar yang cukup baik, namun pertumbuhan tajuk kurang baik, sedangkan perlakuan $\mathrm{T}_{\mathrm{e}}$ menunjukkan pertumbuhan akar dan tajuk yang cukup baik. Pada tanaman karet, interaksi batang bawah dan mata tunas menentukan pertumbuhan dan produksi sebagaimana dilaporkan oleh Nascimento et al. (2011) dan Yuan et al. (2011). Batang bawah yang direkomendasikan adalah yang berasal dari biji klon GT 1, AVROS 2037, BPM 24, PB 260, dan RRIC 100 (Boerhendhy 2009).

\section{Persentase Keberhasilan Okulasi}

Berdasarkan umur batang bawah yang digunakan, okulasi dibedakan menjadi okulasi cokelat (umur batang bawah 7-12 bulan), okulasi hijau (4-7 bulan), dan okulasi dini (2-4 bulan) (Junaidi et al. 2014). Pada penelitian ini, tanaman diokulasi dengan teknik okulasi dini menggunakan masa sisik. Persentase keberhasilan tertinggi diperoleh pada perlakuan $\mathrm{Tb}_{\mathrm{b}}$ $(64,71 \%)$, sedangkan terendah diperoleh pada perlakuan $T_{a}(33,33 \%)$. Perlakuan $T_{c}, T_{d}$, dan $T_{e}$ menunjukkan persentase keberhasilan yang relatif sama, masing-masing sebesar $47,62 \%, 47,62 \%$, dan 47,37\% (Gambar 4). Keberhasilan okulasi dipengaruhi oleh banyak faktor. Berdasarkan hasil penelitian terdahulu, beberapa faktor yang memengaruhi

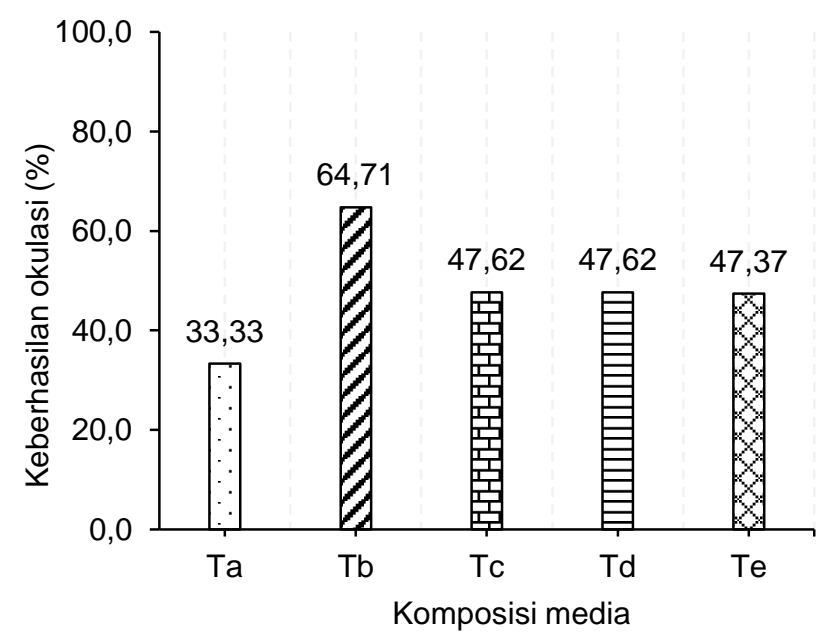

Gambar 4 Persentase keberhasilan okulasi pada masingmasing komposisi bahan tanam. keberhasilan okulasi antara lain adalah umur batang bawah (Heryana et al. 2014), waktu pelaksanaan okulasi (Pudjiono \& Adinugraha 2013), dan jenis mata entres (Udayakumara \& Seneviratne 2005; Junaidi et al. 2014). Keberhasilan okulasi juga dipengaruhi oleh aktivitas kambium. Sariningtias et al. (2014) menyatakan bahwa keberhasilan okulasi akan tinggi jika dilakukan pada periode sel kambium sedang aktif membelah. Selain itu, Kumar (2011) menyatakan bahwa keberhasilan okulasi dipengaruhi oleh waktu pelaksanaan (musim dan cuaca), kompatibilitas batang atas dan mata tunas, umur jaringan tanaman, suhu, dan kelembapan tanah.

Penelitian ini menunjukkan bahwa secara statistik perlakuan yang diujicobakan tidak berbeda nyata dalam keberhasilan okulasi. Meskipun persentase keberhasilan okulasi tertinggi ditemukan pada perlakuan $\mathrm{T}_{b}$, perlakuan $\mathrm{T}_{\mathrm{b}}$ tidak menunjukkan pertumbuhan tajuk yang meyakinkan. Berdasarkan pertimbangan beberapa parameter yang diamati, perlakuan $T_{e}$ dengan media tanam campuran tandan kosong, decanter solid, dan richoderma viride adalah perlakuan yang paling potensial dikembangkan lebih lanjut untuk pembibitan karet dengan metode root trainer. Potensi penggunaan media ini juga didukung oleh ketersediaan bahan dalam jumlah banyak dan kontinyu. Tandan kosong dan decanter solid merupakan limbah hasil pengolahan kelapa sawit (Loekito 2002; Susilawati \& Supijatno 2015). Dengan luas perkebunan kelapa sawit yang mencapai lebih dari 16 juta ha dan ratusan pabrik pengolahan kelapa sawit yang tersebar di seluruh wilayah Indonesia, ketersediaan kedua bahan ini relatif melimpah. Adapun Trichoderma viride adalah spesies jamur yang hidup di tanah sehingga dapat diisolasi dan diperbanyak sesuai kebutuhan (Waghunde et al. 2016; Shah \& Afiya 2019). Penggunaan Trichoderma viride selain dapat meningkatkan pertumbuhan tanaman juga sebagai antisipasi terhadap penyakit jamur akar putih $(R$. microphorus).

\section{KESIMPULAN}

Berdasarkan hasil penelitian ini, media tanam yang berasal dari kombinasi campuran pupuk kandang, decanter solid, sekam padi, dan Trichoderma viride tidak berpengaruh signifikan pada pertumbuhan dan keberhasilan okulasi batang bawah tanaman karet. Namun demikian, media tanam campuran decanter solid dan Trichoderma viride dengan perbandingan 1 : 1 (perlakuan $\mathrm{T}_{\mathrm{e}}$ ) potensial dikembangkan untuk pembibitan root trainer. Penelitian lanjutan diperlukan untuk mengamati pertumbuhan tanaman di lapangan.

\section{UCAPAN TERIMA KASIH}

Penelitian ini dibiayai oleh kerja sama penelitian antara Balai Penelitian Sungei Putih, Pusat Penelitian 
Karet dan Sekolah Tinggi Ilmu Pertanian Agrobisnis Perkebunan (STIPAP) Medan tahun anggaran $2018 / 2019$. Penulis mengucapkan terima kasih kepada kedua lembaga tersebut atas dukungan selama kegiatan penelitian berlangsung.

\section{DAFTAR PUSTAKA}

Ardika R, Herlinawati E. 2014. Alternatif penyediaan bahan tanam karet dengan sistem root trainer. Warta Perkaretan, 33(2): 73-78. https://doi.org/ 10.22302/ppk.wp.v33i2.52

Ardika R, Sanchez PB, Badayos RB, Cruz PCS. 2017. Growth of PB 260 clone (Hevea brasiliensis (Willd. ex A. Juss.) Muell-Arg.) in different potting media and fertilization scheme. Agrivita. 39(2): 182-191. https://doi.org/10.17503/agrivita.v39i2.956

Bashir A, Qaisar KN, Khan MA, Majeed M. 2009. Benefit-cost analysis of raising Pinus wallichiana seedlings in different capacities/sizes of root trainers in the nursery. Forestry Studies in China, 11(2): 118-121. https://doi.org/10.1007/s11632009-0020-7

Boerhendhy I. 2009. Penglolaan biji karet untuk bibit. Warta Penelitian Dan Pengembahan Pertanian, 31(5): 6-9.

Boerhendy I, Agustina DS, Setiono. 2012. Paket teknologi karet untuk mempersingkat masa tanaman belum menghasilkan kurang dari empat tahun. Prosiding Konferensi Nasional Karet, Yogyakarta 1920 September 2012, 269-278. Yogyakarta (ID).

Budiyanto F. 2018. Pengaruh tandan kosong kelapa sawit sebagai media tumbuh jamur terhadap produksi dan sifat fisik jamur merang (Volvariella volvacea). Jurnal Agroindustri. 8(1): 80-96. https:// doi.org/10.31186/jagroindustri.8.1.80-96

Deslauriers A, Giovannelli A, Rossi S, Castro G, Fragnelli G, Traversi L. 2009. Intra-annual cambial activity and carbon availability in stem of poplar. Tree Physiology. 29: 1223-1235. https://doi.org/10.1093/treephys/tpp061

Direktorat Jenderal Perkebunan. (2018). Statistik Perkebunan Indonesia 2017-2019: Kelapa Sawit. In Kementerian Pertanian. Direktorat Jenderal Perkebunan, Kementerian Pertanian. Jakarta (ID).

Fairuzah Z, Dalimunthe Cl, Karyudi K, Suryaman S, Widhayati WE. 2014. Keefektifan beberapa fungi antagonis (Tricoderma sp.) dalam biofungisida Endohevea terhadap penyakit jamur akar putih (Rigidoporus microporus) di lapangan. Jurnal Penelitian Karet. 32(2): 122-128. https:// doi.org/10.22302/jpk.v32i2.158

Feng A, Lingxue K, Lidan G, Zhenhui W, Weifu L. 2011.
Involvement of rootstocks and their hydraulic conductance in the drought resistance of grafted rubber trees. African Journal of Biotechnology. 10(51): 10393-10404. https://doi.org/10.5897/ AJB11.354

George S, Idicula SP, Soman TA, Syamala VK. 2013. Field performance of polybag and root trainer rubber plants at different stages of growth. Rubber Science. 26(2): 197-203.

Harahap AS, Sarman, Rinaldi. 2018. Respons pertumbuhan bibit karet (Hevea brasiliensis Muell. Arg) satu payung klon PB 260 terhadap pemberian decanter solid pada media tanah bekas tambang batu bara di polybag. Agroecotania. 1(1): 33-42.

Heryana N, Saefudin S, Sobari I. 2014. Pengaruh umur batang bawah terhadap persentase keberhasilan okulasi hijau pada tiga klon karet (Hevea brasiliensis Muell Agr.). Jurnal Tanaman Industri Dan Penyegar. 1(2): 95. https://doi.org/10.21082/ jtidp.v1n2.2014.p95-100

Junaidi. 2018. Peluang dan tantangan penerapan teknologi root trainer untuk penyediaan bahan tanam karet berdasarkan S-W-O-T analysis. Warta Penelitian Dan Pengembahan Tanaman Industri2. 24(3): 6-9.

Junaidi, Atminingsih, Siagian N. 2014. Pengaruh jenis mata entres dan klon terhadap keberhasilan okulasi dan pertumbuhan tunas pada okulasi hijau di polibeg. Jurnal Penelitian Karet. 32(1): 21-30. https://doi.org/10.22302/jpk.v32i1.146

Kumar GNM. 2011. Propagation of Plants by Grafting and Budding. A Pacific Northwest Extension Publication, PNW496.

Lestari EB. 2016. Pengaruh kombinasi pupuk kandang sapi dan abu sabut kelapa sebagai pupuk utama dalam budidaya tanaman brokoli (Brassica oleracia L.). Planta Tropika. 4(2): 95-100. https://doi.org/ 10.18196/pt.2016.061.95-100

Loekito, H. (2002). Teknologi pengelolaan limbah industri kelapa sawit. Jurnal Teknologi Lingkungan, 3(3), 242-250.

Maryam A, Susila AD, Kartika JG. 2015. Pengaruh jenis pupuk organik terhadap pertumbuhan dan hasil panen tanaman sayuran di dalam Nethouse. Jurnal Agronomi Dan Hortikultura 3(2): 263-275.

Maryani AT. 2018. Efek pemberian decanter solid terhadap pertumbuhan bibit kelapa sawit (Elaeis guineensis Jacq) dengan media tanah bekas lahan tambang batu bara di pembibitan utama. Caraka Tani, 33(1): 50-56. https://doi.org/10.20961/ carakatani.v33i1.19310

Nascimento ESP, do Oliveira CR, de Gonçalves P, de S, Costa RB, da Moreno RMB, Mattoso LHC, Ferreira AG. 2011. Effect of rootstock on the scion of Hevea brasiliensis through metabolic analysis of 
latex samples by ${ }^{1} \mathrm{H}$ NMR. Crop Breeding and Applied Biotechnology. S1: 82-88. https:// doi.org/10.1590/S1984-70332011000500012

Nayanakantha NMC, Hettiarachchi NN, Seneviratne P, Wathugala DL. 2015. Exogenous nitric oxide donor sodium nitroprusside enhanced growth attributes of polibagged rubber (Hevea brasiliensis) seedlings. Tropical Agricultural Research \& Extension. 18(3): 134-141.

Pudjiono S, Adinugraha HA. 2013. Pengaruh klon dan waktu okulasi terhadap pertumbuhan dan persentase hidup okulasi jati (Tectona grandis). Wana Benih. 14(3): 103-108.

Purwantisari S, Priyatmojo A, Sancayaningsih RP, Kasiamdari RS, Budihardjo K. 2018. Systemic inducing resistance against late blight by applying antagonist Trichoderma viride. IOP Conference Series: Journal of Physics: Conference Series, 1025(1): 012053. https://doi.org/10.1088/17426596/1025/1/012053

Putra MFD, Maghfoer MD, Koesriharti. 2017. Pengaruh jenis pupuk kandang dan dosis pupuk NPK pada hasil tanaman krisan (Chrysanthemum sp.). Jurnal Produksi Tanaman. 5(4): 670-676.

Putra RC, Widyasari T, Achmad SR. 2018. Pengaruh pupuk organik briket gambut rawa pening terhadap pertumbuhan batang bawah tanaman karet dalam root trainer. Jurnal Penelitian Karet. 36(2): 127-136. https://doi.org/10.22302/ppk.jpk.v36i2.599

Rashid M, Rasool M, Lal SB, Masoodi L, Mehboob S. 2018. Effect of root trainers size on quality of seedling production of Jatropha carcus. Journal of Pharmacy and Pharmacology. 7(1): 1551-1554.

Rohaeni N. 2017. Pemanfaatan berbagai limbah padat pabrik kelapa sawit terhadap pertumbuhan dan hasil tanaman terung gelatik (Solanum Melongena L.). Jurnal Pertanian Terpadu. 5(2): 46-57. https:// doi.org/10.36084/jpt..v5i2.126

Salisu MA, Daud WN, Halim RA, Sulaiman Z. 2016. Effect of soilless media on growth and some physiological traits of rubber (Hevea brasiliensis) seedlings. International Journal of Agriculture, Forestry and Plantation. 3: 95-100.

Saputra J, Stevanus CT. 2019. Aplikasi kompos tandan kosong kelapa sawit pada tanaman karet menghasilkan. Warta Perkaretan. 38(1): 1-10. https://doi.org/10.22302/ppk.wp.v1i1.587

Sariningtias NW, Poerwanto R, Gunawan E. 2014. Penggunaan Benzil Amino Purin (BAP) pada okulasi jeruk keprok (Citrus reticulata). Jurnal Hortukultura Indonesia. 5(3): 158-167.

Setiadi D, Noertjahyani, Suparman. 2018. Perbedaan kualitas dan vase life bunga krisan akibat aplikasi macam pupuk organik dengan variasi jarak tanam. Jurnal Kultivasi. 17(1): 587-595.
Setyawan B, Pawirosoemardjo S, Hadi H. 2013. Biofungisida Triko Combi sebagai salah satu pengendali jamur akar putih pada tanaman karet. Warta Perkaretan. 32(2): 83-94. https://doi.org/ 10.22302/ppk.wp.v32i2.40

Shah MM, Afiya H. 2019. Introductory chapter: identification and isolation of Trichoderma spp.Their significance in agriculture, human health, industrial and environmental application. In Trichoderma-The Most Widely Used Fungicide (pp. 1-12). InTech. https://doi.org/10.5772/57353

Siagian N, Bukit E. 2015. Komparasi teknis dan finansial pengadaan benih melalui okulasi tanaman di polibeg dengan okulasi di lapangan. Warta Perkaretan. 34(2): 115-126. https://doi.org/ 10.22302/ppk.wp.v34i2.253

Spicer R, Groover A. 2010. Evolution of development of vascular cambia and secondary growth. New Phytologist. 186(3): 577-592. https://doi.org/10. 1111/j.1469-8137.2010.03236.x

Sudarsono W, Melati M, Aziz S. 2013. Pertumbuhan, serapan hara dan hasil kedelai organik melalui aplikasi pupuk kandang sapi. Indonesian Journal of Agronomy. 41(3): 202-208. https://doi.org/ 10.24831/jai.v41i3.8097

Susilawati, Supijatno. 2015. Pengelolaan limbah kelapa sawit (Elaeis quineensis Jacq.) di perkebunan kelapa sawit, Riau. Buletin Agrohorti. 3(2): 203-212. https://doi.org/10.1145/3132847. 3132886

Topolovec-Pintaric S, Zutic I, Dermic E. 2013. Enhanced growth of cabbage and red beet by Trichoderma viride. Acta Agriculturae Slovenica. 101(1): 87-92. https://doi.org/10.2478/acas-20130010

Udayakumara EPN, Seneviratne P. 2005. Position of the bud on the bud stick on success of bud graft and growth Hevea brasiliensis (Muel Arg). The Journal of Agricultural Science. 1(1): 31-40.

Waghunde RR, Shelake RM, Sabalpara AN. 2016. Trichoderma: A significant fungus for agriculture and environment. African Journal of Agricultural Research. 11(22): 1952-1965. https://doi.org/ 10.5897/AJAR2015.10584

Wang L, Ruan YL. 2016. Shoot-root carbon allocation, sugar signalling and their coupling with nitrogen uptake and assimilation. Functional Plant Biology, 43(2): 105. https://doi.org/10.1071/FP15249

Wattanasilakorn S, Sdoodee S, Nualsri C, Chuenchit, S. 2012. Screening of rubber (Hevea brasiliensis Muell. Arg.) rootstocks for the white root disease resistance. Journal of Agricultural Technology. 8(7): 2385-2395.

Wattanasilakorn S, Sdoodee S, Nualsri C, Chuenchit S, Meesawat U, Sopharat J. 2017. Assessment of 
rubber clonal rootstocks for the tolerance of white root disease (Rigidoporus microporus) in Southern Thailand. Walailak Journal of Science and Technology. 14(7): 549-561. https://doi.org/ 10.14456/vol14iss9pp

Yuan K, Ding X, Yang LF, Wang ZH, Lin WF, Cao JH. 2011. Proteome analysis of interaction between rootstocks and scions in Hevea brasiliensis. African Journal of Biotechnology. 10(66): 14816-14825.

Yulia EY, Istifadah N, Widiantini F, Utami HS. 2017.
Antagonisme Trichoderma spp. terhadap jamur Rigidoporus lignosus (Klotzsch) Imazeki dan penekanan penyakit jamur akar putih pada tanaman karet. Agrikultura. 28(1): 47-55. https://doi.org/ 10.24198/agrikultura.v28i1.13226

Zegeye ED, Santhanam A, Gorfu D, Kassa B. 2011. Biocontrol activity of Trichoderma viride and Pseudomonas fluorescens against Phytophthora infestans under greenhouse conditions. Journal of Agricultural Technology. 7(6): 1589-1602. 